\title{
PRODUCTION OF 'KEDONDONG' (SPONDIAS CYTHEREA SONNERAT) POWDER AS AFFECTED BY DIFFERENT DRYING METHODS
}

\author{
Lee Sin Chang ${ }^{1}$, Kar Qi Lau², Chin Ping Tan³, Yus Aniza Yusof ${ }^{4}$, Kar Lin Nyam², \\ Liew Phing Pui ${ }^{2 \otimes}$
}

${ }^{1}$ Department of Food Sciences, Universiti Kebangsaan Malaysia

43600 UKM Bangi, Selangor, Malaysia

${ }^{2}$ Department of Food Science and Nutrition, UCSI University

No. 1 Jalan Menara Gading, UCSI Heights, 56100 Kuala Lumpur, Malaysia

${ }^{3}$ Department of Food Technology, Universiti Putra Malaysia

43400 Serdang, Selangor, Malaysia

${ }^{4}$ Department of Process and Food Engineering, Universiti Putra Malaysia

43400 Serdang, Selangor, Malaysia

\begin{abstract}
Background. 'Kedondong' fruit is regarded as an exotic fruit that is gaining popularity due to its deliciousness and pleasant flavour. However, this fruit has a short shelf life, leading to problems with postharvest loss. In order to prevent losses, the fruit could be produced as a value-added product. In this study, the 'kedondong' fruit was preserved by drying into powder using different drying methods.

Materials and methods. The kedondong powder was dried using five methods: convection oven drying, vacuum drying, spray drying, drum drying and freeze drying. The physical properties, flowability and DPPH radical scavenging ability of dried kedondong powder were examined.

Results. Spray-dried powder provided the significantly $(p \leq 0.05)$ highest process yield, which was $54.93 \%$. All the powder produced had a low moisture content (3.03 to 5.66\%) and water activity (0.19-0.37). Visually, whitish and fine powders were observed on spray-dried and freeze-dried samples, while convection oven-dried and vacuum-dried powder appeared yellowish and coarse. The $\mathrm{pH}$ of the reconstituted powders varied from 2.71 to 2.83, where drum-dried powder was the most acidic. Spray-dried powder showed the highest wettability and shortest dissolution time, which was $172.65 \mathrm{~s}$ and $10.55 \mathrm{~s}$, respectively. With the exception of drum-dried powder, all the dried powders were classified as non-caking powders. The bulk and tapped density of the powders ranged from 0.32 to $0.70 \mathrm{~g} / \mathrm{mL}$ and 0.38 to $0.86 \mathrm{~g} / \mathrm{mL}$, respectively. Vacuum-dried powder had very good flowability, convection oven-dried and drum-dried powder had good flowability, while spray-dried and drum-dried powder had fair flowability. Antioxidant assay showed that freeze-dried powder exhibited the highest free radical scavenging activity $\left(\mathrm{IC}_{50}=701.29 \mu \mathrm{g} / \mathrm{mL}\right)$.

Conclusion. This study indicates that spray-dried kedondong powder has great potential in the food industry due to its high process yield and better powder quality. Meanwhile, freeze drying best preserved the antioxidant properties of the powder, which could potentially be used as a functional ingredient as a result. This study is important for the fruit processing industry as it offers an alternative for the farmer to produce kedondong fruit powder because the fruit has a short shelf life. Converting the fruit into powder can diversify the resulting produce into different applications, such as fruit juice, beverages, jam and other food products.
\end{abstract}

Keywords: antioxidant, drying, flowability, kedondong, powder, solubility 


\section{INTRODUCTION}

'Kedondong' (Spondias cytherea Sonnerat) is a tropical fruit belonging to the Anacardiaceae family (Franquin et al., 2005), commonly known as golden apple or ambarella. It is one of the most treasured exotic fruits and is gaining popularity due to its deliciousness and pleasant flavour. However, 'kedondong' fruit is climacteric, with a high respiration rate and ethylene production, giving it a short shelf life (Katerson and Badrie, 2002). This climacteric nature accelerates quality losses through physical and chemical changes, such as colour breakdown and disease potential, which results in reduced market value and functionality (Badrie and Schauss, 2010). Therefore, to prevent post-harvest losses, this fruit can be transformed into value-added commercial products, such as 'kedondong' powder, which is a beneficial alternative before the fruit loses its utilities (Chang et al., 2018b).

Production of fruit powder is a promising approach to reduce the costs of packaging, storage and transportation (Mujumdar, 2015). More importantly, fruit powder can be stored for a longer period than fresh fruit. This is because the moisture content in a powder is at microbiologically safe levels as the water activity is very low (Chew et al., 2019). Hence, preserving fruit as powder helps to mitigate the problems of short shelf life, overproduction and financial loss (Mujumdar, 2015). Moreover, fruit powder offers innovative formulations and new markets (Caparino et al., 2012) as it can be consumed as an instant fruit drink or health drink after dissolving in water or used as an ingredient in baby food, ice-cream, yogurt and confections to enhance the colour, flavour and nutritional value of products (Lai et al., 2020; Ng et al., 2019; Pui et al., 2020).

There are several drying methods in the food industry for the production of fruit powders, including convection oven drying, vacuum oven drying, spray drying, freeze drying and drum drying (Barbosa et al., 2015; Park et al., 2016; Pui et al., 2018). Each drying method has its own advantages and drawbacks. Since different drying methods operate under different conditions, powders with different physical properties are produced. Numerous research studies on common fruit drying have been extensively conducted for chempedak (Pui et al., 2018), papaya (Chang et al., 2020b) and pineapple (Wong et al., 2015). Yet research on other fruits, particularly exotic and tropical fruits, is rather scarce. To date, scientific information on 'kedondong' is limited and production of 'kedondong' powder has not been reported. Hence, this study aimed to investigate the properties of 'kedondong' powder produced by different drying methods. This study is expected to produce a shelf-stable 'kedondong' powder that is able to benefit the farmer and broaden its application in the food ingredient industry.

\section{MATERIALS AND METHODS}

\section{Materials}

Fresh 'kedondong' (Spondias cytherea Sonnerat) was collected and purchased from a local supermarket located in Kuchai Lama, Kuala Lumpur, Malaysia. The selected 'kedondong' was uniform in size $(10-12 \mathrm{~cm}$ length) and colour (green), with minimal surface defects and at commercial maturity. The chemicals used in all analyses were analytical grade and were purchased from Sigma-Aldrich, UK.

\section{Preparation of 'kedondong' feed}

The fruit was washed thoroughly under running tap water to remove surface dirt, then peeled and deseeded. The flesh was cut into small pieces $\left(2 \times 2 \times 2 \mathrm{~cm}^{3}\right)$ and blended into puree using a food blender. The puree was incorporated with maltodextrin of $50 \%(\mathrm{w} / \mathrm{v})$ for all drying methods. Maltodextrin was added as a drying aid to overcome the stickiness of the powder during the drying process due to the presence of low molecular weight compounds such as sugar and organic acid. This level was deduced from the preliminary working, which showed the production of powder with low levels of maltodextrin $(<30 \%)$, resulting in a sticky powder with a high degree of caking.

\section{Drying process}

The drying process of 'kedondong' fruit using different methods is summarised in the supplementary table (Table 1). The 'kedondong' puree was spread evenly on a stainless-steel tray and heated in a convection oven (CD) (Memmert, Germany) at $45^{\circ} \mathrm{C}$ for 48 hours and a vacuum oven (VD) (VD23, Binder, Germany) at $70^{\circ} \mathrm{C}$ for 24 hours under 100 mbar. A mini spray dryer (B-290, Buchi, Switzerland) was used to prepare spray-dried 'kedondong powder' (SD). 
Chang, L. S., Lau, K. Q., Tan, C. P., Yusof, Y. A., Nyam, K. L., Pui, L. P. (2021). Production of 'kedondong' (Spondias cytherea Sonnerat) powder as affected by different drying methods. Acta Sci. Pol. Technol. Aliment., 20(4), 417-427. http://dx.doi.org/10.17306/ J.AFS.2021.0903

Table 1. Supplementary table. Methods used in drying of 'kedondong' fruit

\begin{tabular}{|c|c|c|c|c|}
\hline Drying method & Temperature & Time, $\mathrm{h}$ & Machine & Abbreviation \\
\hline $\begin{array}{l}\text { Convection oven } \\
\text { drying }\end{array}$ & $45^{\circ} \mathrm{C}$ & 48 & $\begin{array}{l}\text { convection oven (Memmert, } \\
\text { Germany) }\end{array}$ & $\mathrm{CD}$ \\
\hline Vacuum drying & $70^{\circ} \mathrm{C}$ under $100 \mathrm{mbar}$ & 24 & $\begin{array}{l}\text { vacuum oven (VD23, Binder, } \\
\text { Germany) }\end{array}$ & VD \\
\hline Spray drying & $170^{\circ} \mathrm{C}$, pump at $20 \%$ and aspirator rate at $90 \%$ & 1 & $\begin{array}{l}\text { spray dryer (B-290, Buchi, } \\
\text { Switzerland) }\end{array}$ & $\mathrm{SD}$ \\
\hline Drum drying & $\begin{array}{l}130-140^{\circ} \mathrm{C} \text {, rotate at } 2 \mathrm{rpm} \text {, steam pressure of } \\
3 \text { bar and drum clearance of } 0.02 \mathrm{~mm}\end{array}$ & 1 & $\begin{array}{l}\text { drum dryer (R. Simon Dryers Ltd., } \\
\text { Universal Test Machine, Notting- } \\
\text { ham England) }\end{array}$ & $\mathrm{DD}$ \\
\hline Freeze drying & $-55^{\circ} \mathrm{C}$, vacuum pressure of $0.28 \mathrm{mbar}$ & 48 & $\begin{array}{l}\text { freeze dryer (Alpha 1-2 LDplus, } \\
\text { Martin Christ GmbH, Germany) }\end{array}$ & FD \\
\hline
\end{tabular}

The parameters were set as follows: inlet temperature at $170{ }^{\circ} \mathrm{C}$, pump at $20 \%$ and aspirator rate at $90 \%$ (Chang et al., 2020b). Meanwhile, a double drum dryer (DD) (R. Simon Dryers Ltd., Universal Test Machine, Nottingham England) was used to drum dry the 'kedondong' puree. The drum was set to rotate at $2 \mathrm{rpm}$, and the surface temperature ranged between $130^{\circ} \mathrm{C}$ and $140^{\circ} \mathrm{C}$ with a steam pressure of 3 bar and drum clearance of $0.02 \mathrm{~mm}$. The dried product was scraped off as a thin film and ground into powder (Caparino et al., 2012). Lastly, to prepare freeze-dried 'kedondong' powder (FD), the 'kedondong' puree was pre-frozen in a freezer at $-20^{\circ} \mathrm{C}$ overnight. Then, the frozen puree was subjected to a freeze dryer (Alpha 1-2 LDplus, Martin Christ GmbH, Germany) for 48 hours with a vacuum pressure of 0.28 mbar and condenser temperature at $-55^{\circ} \mathrm{C}$. All the dried powder was collected and sealed in an airtight condition via vacuum packaging and stored at room temperature for further analysis (Wong et al., 2015).

\section{Analysis}

Process yield. The powder was weighed using a balance (XT220A, Precisa, Switzerland) and the process yield was calculated using the equation below (Chang et al., 2020b).

$$
\text { Process yield, } \%=\frac{\begin{array}{c}
\text { weight of produced } \\
\text { powder, } g
\end{array}}{\begin{array}{c}
\text { weight of fruit } \\
\text { puree, } g
\end{array}} \times 100 \%
$$

Moisture content and water activity $\left(A_{w}\right)$. Moisture content was determined using the AOAC 935.29 standard method (AOAC, 1995). Approximately $2 \mathrm{~g}$ of powder was weighed and placed onto the sample pan and heated at $105^{\circ} \mathrm{C}$ for $24 \mathrm{~h}$ until constant weight. $A_{w}$ was determined using an AquaLab Pre water activity meter (Pullman, USA). The powders ( $2 \mathrm{~g}$ ) were poured into a sample cup and placed in the chamber for measurement (Chang et al., 2020b).

Colour. The colour of the powder was measured using a Hunter-Lab ColorFlex EZ spectrophotometer (UK) equipped with EasyMatch QV-ER software for electronic records. The device was first calibrated against a black tile followed by a white tile before the measurement. The powders were poured into a quartz sample cup and placed onto the sample port for measurement. The results were expressed as $L^{*}, a^{*}$, and $b^{*}$, where $L^{*}$ denotes lightness, $a^{*}$ denotes redness and greenness, and $b^{*}$ denotes yellowness and blueness (Chang et al., 2020a).

pH. A pH meter (Jenway 3505, UK) was pre-calibrated with two standard buffers of $\mathrm{pH} 4$ and 7 before measurement. In brief, about $1 \mathrm{~g}$ of powder was dissolved in $5 \mathrm{~mL}$ of distilled water and measured (Caliskan and Dirim, 2013).

Wettability and dissolution. Briefly, $1 \mathrm{~g}$ of powder was added to $100 \mathrm{~mL}$ of distilled water. The time required for the powders to sink beneath the surface of 
the water was recorded using a stopwatch. The time is referred to as wetting time, which represents wettability (Chang et al., 2020a). Meanwhile, about $50 \mathrm{mg}$ of powder was weighed and added to $1 \mathrm{~mL}$ of distilled water. The test tube was vortexed (2000 rpm), and the time required for the powder to fully reconstitute in water was recorded using a stopwatch and expressed as dissolution (Barbosa et al., 2015).

Degree of caking. Degree of caking was determined according to Goula and Adamopoulos (2010) with some modifications. A sieve of $500 \mu \mathrm{m}$ was shaken constantly for one minute and the weight of the powder remaining on the sieve was recorded. Degree of caking was calculated using the equation below:

$$
\begin{gathered}
\text { Degree } \\
\text { of caking, } \%
\end{gathered}=\frac{\begin{array}{c}
\text { weight of powder } \\
\text { left on sieve, } g
\end{array}}{\begin{array}{c}
\text { initial weight of } \\
\text { powder, } g
\end{array}} \times 100 \%
$$

Bulk density and tapped density. One gram of powder was poured into a pre-weighed $5 \mathrm{~mL}$ measuring cylinder and the volume of powder occupied was recorded. Bulk density was calculated using the equation below (Begum et al., 2017).

$$
\text { Bulk density, } \rho \mathrm{B}=\frac{\text { weight of powder, } \mathrm{g}}{\text { volume of powder, } \mathrm{g}} \times 100 \%
$$

After the initial volume was recorded, the cylinder was tapped mechanically to reach a constant volume. The tapped density was calculated using the following equation (Begum et al., 2017):

$$
\begin{gathered}
\text { Tapped } \\
\text { density, } \rho \mathrm{T}
\end{gathered}=\frac{\begin{array}{c}
\text { weight } \\
\text { of powder, } g
\end{array}}{\begin{array}{c}
\text { constant volume } \\
\text { of powder, } g
\end{array}} \times 100 \%
$$

Flowability (Carr index) and cohesiveness (Hausner ratio). The Carr index is correlated to powder flowability while the Hausner ratio represents the cohesiveness of the powder (Begum et al., 2017). The Carr index and Hausner ratio were calculated using the following equations:
Carr index, \% CI $=\frac{\begin{array}{c}\text { tapped density }- \\ - \text { bulk density }\end{array}}{\begin{array}{c}\text { tapped } \\ \text { density }\end{array}} \times 100 \%$

$$
\text { Hausner ratio, } \mathrm{HR}=\frac{\text { tapped density }}{\text { bulk density }}
$$

\section{2,2-diphenyl-1-picrylhydrazyl (DPPH) free radical} scavenging activity. Fresh 'kedondong' puree $(10 \mathrm{~g})$ and powders were extracted in 70\% methanol (70:30 methanol in water) for 24 hours and the methanol was distilled off at $50^{\circ} \mathrm{C}$ using a rotary vacuum evaporator. The extracts $(50 \mathrm{mg})$ were used to prepare a stock solution of $500 \mu \mathrm{g} / \mathrm{mL}$ in methanol. Then, different concentrations of extracts $(250,100,50,25,16.67$ and $12.5 \mu \mathrm{g} / \mathrm{mL}$ ) were prepared by diluting the stock solution. The extracts $(2 \mathrm{~mL})$ were added to $1 \mathrm{~mL}$ of DPPH solution (5.9 mg in $100 \mathrm{~mL}$ methanol) and measured at $517 \mathrm{~nm}$ after being stored in the dark for 30 minutes. Radical scavenging activity was calculated using the following equation (Caliskan and Dirim, 2013).

$$
\begin{gathered}
\text { Radical scavenging } \\
\text { activity, } \%
\end{gathered}=\frac{A_{\text {control }}-A_{\text {sample }}}{A_{\text {control }}} \times 100 \%
$$

where:

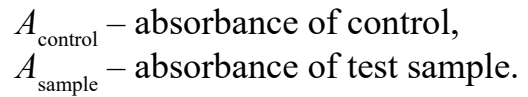

Statistical analysis. The data collected was expressed in terms of mean \pm standard deviations. All statistical analysis of the data collected from the experiment was analyzed using Minitab v.18 LLC (USA). Oneway ANOVA was performed to determine the significant differences between the means of data collected $(p \leq 0.05)$.

\section{RESULTS AND DISCUSSION}

\section{Process yield}

According to Figure 1, the process yield of powder obtained from different drying methods ranged from 20.79 to $54.93 \%$. It was observed that powder yielded from DD and FD were significantly the lowest $(p \leq$ 0.05 ). The lower process yield of drum drying was due 


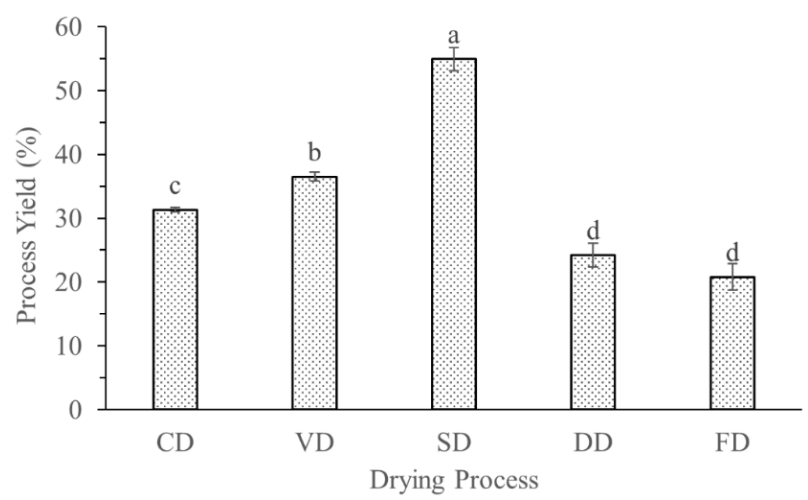

Fig. 1. Process yield, \%, of convection oven dried $-\mathrm{CD}$, vacuum oven dried - VD, spray dried - SD, drum dried DD and freeze dried - FD 'kedondong' powders

to the loss of final products from the drum surfaces as the sugar content of the kedondong fruit was high and the dried product was sticky and adhered to the surface of the drum. The final dried product rolled and built up while the drum was rotating and formed an extrudedlike product (Caparino et al., 2012). The lower process yield of freeze drying was consistent with the findings that freeze drying had a low drying rate that led to a relatively low process yield (Michalska et al., 2016). Meanwhile, the powder produced from the spray drying method was significantly $(p \leq 0.05)$ the highest.

\section{Moisture content and water activity $\left(A_{w}\right)$}

Figure 2 shows the moisture content and $A_{w}$ of 'kedondong' powder produced from different drying methods. In general, the moisture content of the powders varied from 3.03 to $5.66 \%$ and Aw from 0.19 to 0.37 . According to Tan et al. (2015), biochemical and microbiological reactions in a food system are inhibited and deterioration of products can be prevented when the moisture content is $<6 \%$. In addition, dried product with $A_{w}<0.60$ is considered microbiologically stable, and a water activity within 0.20 to 0.40 ensures the stability of a product against the browning reaction, lipid oxidation, auto-oxidation and enzymatic activity (Caliskan and Dirim, 2013). These values indicate that the powders produced in this study met these requirements and were considered biochemically and microbiologically stable, exhibiting good powder stability during storage.

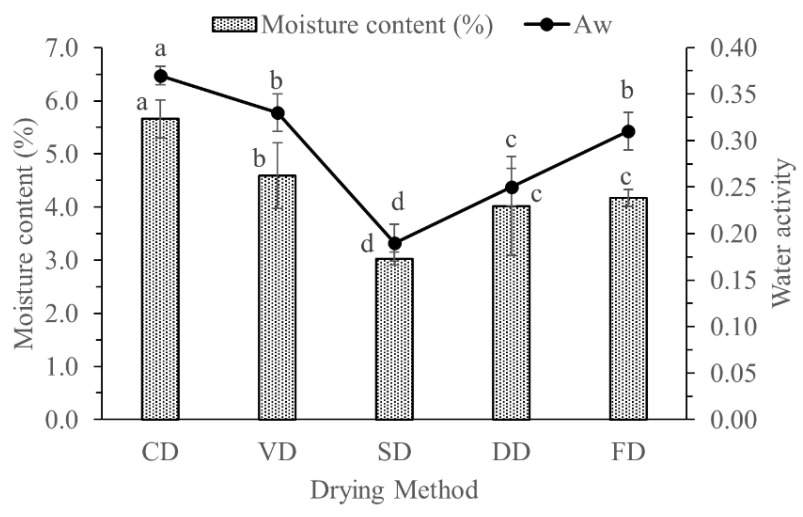

Fig. 2. Moisture content, $\%$, and water activity $-A_{w}$ of convection oven dried $-\mathrm{CD}$, vacuum oven dried - VD, spray dried - SD, drum dried - DD and freeze dried - FD 'kedondong' powders

The moisture content and Aw of spray dried powder were found to be lower $(p \leq 0.05)$ than the other drying methods. This may be due to the high temperature of the spray drying process, which promotes a high rate of heat transfer that provides a greater driving force for moisture evaporation, and thus produces powder with a lower moisture content (Caliskan and Dirim, 2013). In contrast, powder produced by CD showed the significantly $(p \leq 0.05)$ highest moisture content and $A_{w}$, probably due to the low temperature applied during convection drying $\left(45^{\circ} \mathrm{C}\right)$.

\section{Colour}

Colour is an important attribute that reflects consumer acceptance and potential applications of the powder. Figure 3 shows the visual observation of powder produced by different drying methods. Visually, the SD powder (Fig. 3c) appeared very fine while the FD powder (Fig. 3e) exhibited a whitish powder. The CD (Fig. 3a) and VD (Fig. 3b) powders appeared yellowish and coarse, while the DD powder (Fig. 3d) was slightly white and finer than the CD and VD powders but coarser than the SD and FD powders. All these observations agreed with the results given in Table 2 that there was no significant difference $(p>0.05)$ in colour parameters $\left(L^{*}, a^{*}\right.$ and $\left.b^{*}\right)$ between the SD and FD powders, indicating no difference in lightness, redness and yellowness between the SD and FD powders. In addition, these two powders also exhibited the highest $L^{*}$ value compared to the other powders. This might 


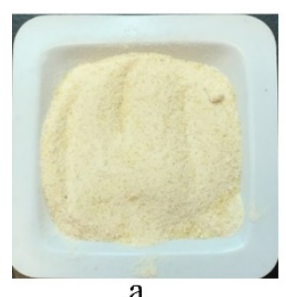

a

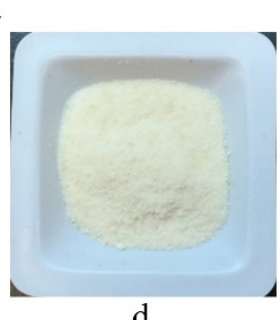

d

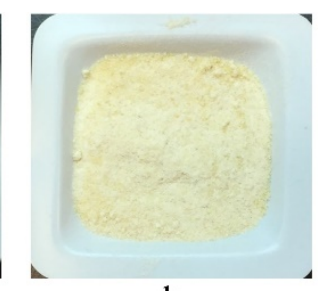

b

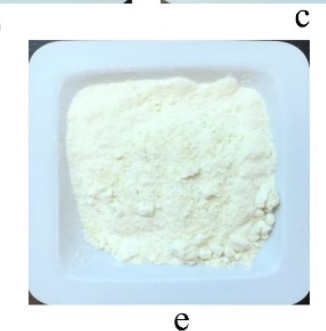

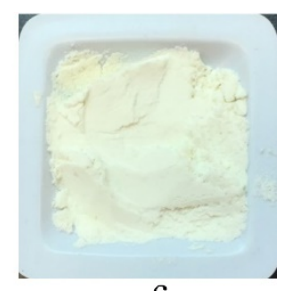
c

Fig. 3. Visual observation of 'kedondong' powder by: a - convection oven drying, $\mathrm{b}$ - vacuum drying, $\mathrm{c}$ - spray drying, $\mathrm{d}$ - drum drying, e - freeze drying

Table 2. Colour parameters of dried 'kedondong' powder using different drying methods $(n=3)$

\begin{tabular}{lccc}
\hline \multirow{2}{*}{$\begin{array}{c}\text { Drying } \\
\text { methods }\end{array}$} & \multicolumn{3}{c}{ Colour parameters } \\
\cline { 2 - 4 } & $L^{*}$ & \multicolumn{1}{c}{$a^{*}$} & $b^{*}$ \\
\hline CD & $75.53 \pm 0.67^{\mathrm{c}}$ & $4.67 \pm 0.29^{\mathrm{a}}$ & $22.44 \pm 1.35^{\mathrm{a}}$ \\
VD & $81.75 \pm 2.84^{\mathrm{b}}$ & $3.39 \pm 0.11^{\mathrm{b}}$ & $24.57 \pm 0.60^{\mathrm{a}}$ \\
$\mathrm{SD}$ & $91.41 \pm 0.11^{\mathrm{a}}$ & $-1.52 \pm 0.03^{\mathrm{d}}$ & $10.92 \pm 0.28^{\mathrm{c}}$ \\
DD & $83.68 \pm 0.61^{\mathrm{b}}$ & $1.11 \pm 0.06^{\mathrm{c}}$ & $15.57 \pm 0.86^{\mathrm{b}}$ \\
FD & $90.31 \pm 0.52^{\mathrm{a}}$ & $-1.29 \pm 0.27^{\mathrm{d}}$ & $9.41 \pm 1.33^{\mathrm{c}}$ \\
\hline
\end{tabular}

a-d Different letters in the same column denotes statistical significance at $p \leq 0.05$.

$\mathrm{CD}$ - convection oven drying, VD - vacuum drying, SD spray drying, DD - drum drying, FD - freeze drying.

be due to the short drying time employed during spray drying, which reduced the degradation of colour (Caparino et al., 2012) and the low temperature condition in freeze drying that prevents browning of the sugar compound (Park et al., 2016). Meanwhile, the fact that the lowest $L^{*}$ value was recorded in the CD powder was probably due to the direct exposure of the puree surface to hot air during drying. Similar results were observed on the kimchi powder, in which the browning index of hot air-dried kimchi powder was higher than powder from freeze drying (Park et al., 2016). A similar reason was proposed for the low $L^{*}$ value in the VD and DD powders. On the other hand, the SD and FD powders exhibited negative $a^{*}$ values, indicating a tendency to a slight greenish colour, whereas CD, DD and VD exhibited positive $a^{*}$ values, indicating a tendency to a reddish colour. The slight redness of powders was attributed to the browning reaction or Maillard reaction caused by chemical reactions between sugars and proteins (Caparino et al., 2012). Furthermore, caramelisation of sugars can occur due to the higher temperature applied during drying (Caparino et al., 2012). Meanwhile, significantly higher $(p \leq 0.05)$ positive $b^{*}$ values were observed in the CD and VD powders, indicating a higher tendency to a yellowish colour, which may be caused by the browning reaction due to sugar content and heat supplied during the drying process (Caparino et al., 2012). Lower $b^{*}$ values in the SD and FD powders indicated that the low temperature and short time drying operations are able to preserve the yellowness of the powder without the browning reaction occurring.

\section{$\mathrm{pH}$}

Table 3 summarises the physical properties of 'kedondong' powder from different drying methods. From the results, the $\mathrm{pH}$ values of reconstituted 'kedondong' powders were in between 2.66-2.83, indicating that 'kedondong' powder is acidic in nature. The value of 
Chang, L. S., Lau, K. Q., Tan, C. P., Yusof, Y. A., Nyam, K. L., Pui, L. P. (2021). Production of 'kedondong' (Spondias cytherea Sonnerat) powder as affected by different drying methods. Acta Sci. Pol. Technol. Aliment., 20(4), 417-427. http://dx.doi.org/10.17306/ J.AFS.2021.0903

Table 3. The physical properties of dried 'kedondong' powder using different drying methods $(n=3)$

\begin{tabular}{ccccccccc}
\hline $\begin{array}{c}\text { Drying } \\
\text { methods }\end{array}$ & $\mathrm{pH}$ & $\begin{array}{c}\text { Wettability } \\
\mathrm{s}\end{array}$ & $\begin{array}{c}\text { Dissolution } \\
\mathrm{s}\end{array}$ & $\begin{array}{c}\text { Degree of } \\
\text { caking } \\
\%\end{array}$ & $\begin{array}{c}\text { Bulk density } \\
\mathrm{g} / \mathrm{mL}\end{array}$ & $\begin{array}{c}\text { Tapped } \\
\text { density } \\
\mathrm{g} / \mathrm{mL}\end{array}$ & $\begin{array}{c}\mathrm{Cl} \\
\%\end{array}$ & $\mathrm{HR}$ \\
\hline $\mathrm{CD}$ & $2.83 \pm 0.02^{\mathrm{a}}$ & $5.54 \pm 1.45^{\mathrm{d}}$ & $42.01 \pm 1.45^{\mathrm{a}}$ & $4.33 \pm 0.12^{\mathrm{c}}$ & $0.70 \pm 0.02^{\mathrm{a}}$ & $0.86 \pm 0.01^{\mathrm{a}}$ & $16.19 \pm 3.3^{\mathrm{d}}$ & $1.23 \pm 0.06^{\mathrm{ab}}$ \\
$\mathrm{VD}$ & $2.73 \pm 0.09^{\mathrm{bc}}$ & $42.35 \pm 1.84^{\mathrm{c}}$ & $35.92 \pm 1.68^{\mathrm{b}}$ & $6.53 \pm 0.74^{\mathrm{b}}$ & $0.75 \pm 0.03^{\mathrm{a}}$ & $0.88 \pm 0.02^{\mathrm{a}}$ & $14.87 \pm 3.1^{\mathrm{e}}$ & $1.17 \pm 0.05^{\mathrm{b}}$ \\
$\mathrm{SD}$ & $2.71 \pm 0.02^{\mathrm{bc}}$ & $172.65 \pm 5.30^{\mathrm{a}}$ & $10.55 \pm 0.04^{\mathrm{e}}$ & $2.51 \pm 0.54^{\mathrm{d}}$ & $0.32 \pm 0.01^{\mathrm{d}}$ & $0.38 \pm 0.03^{\mathrm{d}}$ & $22.29 \pm 0.43^{\mathrm{b}}$ & $1.30 \pm 0.04^{\mathrm{a}}$ \\
$\mathrm{DD}$ & $2.66 \pm 0.04^{\mathrm{c}}$ & $49.07 \pm 1.40^{\mathrm{c}}$ & $31.46 \pm 0.48^{\mathrm{c}}$ & $10.47 \pm 0.97^{\mathrm{a}}$ & $0.49 \pm 0.01^{\mathrm{c}}$ & $0.65 \pm 0.02^{\mathrm{c}}$ & $24.47 \pm 0.23^{\mathrm{a}}$ & $1.30 \pm 0.01^{\mathrm{a}}$ \\
$\mathrm{FD}$ & $2.76 \pm 0.01^{\mathrm{b}}$ & $64.18 \pm 1.55^{\mathrm{b}}$ & $26.45 \pm 0.91^{\mathrm{d}}$ & $1.84 \pm 0.10^{\mathrm{d}}$ & $0.55 \pm 0.02^{\mathrm{b}}$ & $0.70 \pm 0.02^{\mathrm{b}}$ & $17.77 \pm 1.27^{\mathrm{c}}$ & $1.20 \pm 0.01^{\mathrm{b}}$ \\
\hline
\end{tabular}

${ }^{\text {a-d }}$ Different letters in the same column denotes statistical significance at $p \leq 0.05$.

$\mathrm{CD}$ - convection oven drying, VD - vacuum drying, SD - spray drying, DD - drum drying, FD - freeze drying, CI - Carr index, HR - Hausner ratio.

'kedondong' fruit in this study was close to the reported value (2.6) from fruit harvested from Martinique, French West Indies, showing that it is an acidic fruit regardless of its origin (Franquin et al., 2005). In addition, the higher $\mathrm{pH}$ value of the powder than fresh fruit (2.6) suggested that some organic acids were lost due to evaporation during drying, leading to higher $\mathrm{pH}$ values of the powders (Caliskan and Dirim, 2013). Meanwhile, the CD powder exhibited the significantly $(p \leq 0.05)$ highest $\mathrm{pH}$, indicating lower amounts of acid, while the DD powder demonstrated the significantly $(p \leq 0.05)$ lowest $\mathrm{pH}$, signifying the more acidic powder obtained. This may be due to the higher temperature used in the convective oven drying method that denatures the acidic compound in the fruit, leading to a higher $\mathrm{pH}$ value.

\section{Wettability and dissolution}

Wettability is the first step in the process of dissolution and the wettability time of 'kedondong' powders ranged from 5.54 to $172.65 \mathrm{~s}$. It was observed that $\mathrm{CD}$ displayed the significantly $(p \leq 0.05)$ lowest wettability time while SD had the highest, indicating that SD powder has a low ability to overcome the surface tension to become completely wet as described by Koç and Dirim (2018). These results were similar to the findings of Santhalakshmy et al. (2015), who worked with spray dried jamun juice powder with the wettability time ranging from 93.22 to $116.00 \mathrm{~s}$. The reason for this consequence may be the high temperature applied during spray drying which led to formation of a hard layer and powder with a low moisture content. This was in agreement with Caliskan and Dirim (2013), who found that the sumac powder with the lowest moisture content exhibited the highest wettability. Wettability is inversely related to particle size as larger particles have more spaces and are easily penetrated by water. Meanwhile, spray dried powder possesses a small particle size and is less porous, making it more difficult for water to penetrate through the food matrix (Koç and Dirim, 2018).

On the other hand, dissolution time was in the range of 10.55 to $42.01 \mathrm{~s}$, with SD having the significantly $(p \leq 0.05)$ shortest dissolution time among the drying methods. This value was similar to the finding of Barbosa et al. (2015), who reported the dissolution of spray dried orange powder as $19 \mathrm{~s}$. This is because the high temperature resulted in a higher porosity of powder that led to a greater specific surface area $(\mathrm{Ca}-$ parino et al., 2012). This brings a larger contact surface area between the powder and water during dissolution. There was an inversely proportional relationship between dissolution and moisture content of powder, (the powder with the lowest moisture content had the highest dissolution). This was in agreement with Goula et al. (2004), who observed fast dissolution when the powder had a low moisture content. Meanwhile, a high moisture content led to low dissolution, probably due to the powder with a higher moisture content having a higher tendency to agglomerate, which resulted in an increase in reconstitution time (Barbosa et al., 2015). 


\section{Degree of caking}

Table 3 shows that the degree of caking of the powders ranged from $2.51-10.47 \%$. According to GEA Niro Research Laboratory (GEA, 2019), powders with a caking degree $<10 \%$ are considered as non-caking powders, while $>50 \%$ is a powder with a high degree of caking. Hence, the powders under study were classified as non-caking powders, while DD was considered a slightly caking powder. The slight caking of the DD powder was possibly due to its high moisture content causing the formation of solid bridges, as described by Chang et al. (2018a). In this circumstance, the powder tends to stick together to form lumps in powder bulk or solidification of bed powder, which results in strong powder cohesion and reduced flowability (Chang et al., 2018b). This was in agreement with Goula and Adamopoulos (2010), who found that the caking of powder can be attributed to moisture absorption.

\section{Bulk density and tapped density}

According to Table 3, the bulk density of the powders ranged from 0.32 to $0.75 \mathrm{~g} / \mathrm{mL}$. No significant differences $(p>0.05)$ in bulk density were observed between $\mathrm{CD}$ and VD, however, these two drying methods exhibited the significantly highest $(p \leq 0.05)$ bulk density comparative to the rest of the drying methods. These results were consistent with the findings of Begum et al. (2017). According to their findings, the bulk densities of convection oven-dried and vacuum oven-dried powder were significantly higher than those of spray-dried and freeze-dried powder as these drying methods give a compact and non-porous structure. Caparino et al. (2012) also reported that drum-dried mango powder had the highest bulk density as the high temperature caused a collapse of the structure that resulted in a compact and rigid powder with low porosity. In addition, higher bulk density might be due to the higher moisture content of the powder. These findings are in agreement with Caliskan and Dirim (2013), who found that sumac powder with a higher moisture content tends to have a higher bulk density due to the presence of water, which is considerably denser than the dry solid. Meanwhile, the low bulk density of SD powder was related to the high drying temperature, which promotes a faster moisture evaporation rate from the powder particles, and subsequently forms a porous or fragmented structure of powder with low bulk density (Caliskan and Dirim, 2013).

Tapped density is the maximum packing density of powder that is achieved under the influence of an externally applied force (Ali et al., 2017). The CD and VD powders showed the significantly highest $(p \leq 0.05)$ tapped densities while the SD powder had the lowest. These findings indicate that powder produced by spray-drying method has more intra-particle spaces compared to convection oven-dried and vacuum-dried powders (Begum et al., 2017). These larger number of spaces or voids between particles contribute to a low tapped density.

\section{Flowability (Carr index) and cohesiveness (Hausner ratio)}

Flowability of dried powder as measured by CI value, and cohesiveness as indicated by HR ranged from $14.87-24.47 \%$ and $1.17-1.30$, respectively. According to the classification of powder flowability, CI values of $<15 \%, 15-20 \%, 20-35 \%, 35-40 \%$ and $>45 \%$ were considered as very good, good, fair, bad and very bad flowability, respectively (Koç and Dirim, 2018). Meanwhile, cohesiveness is classified as low, intermediate and highly cohesive when HR is $<1.2,1.2-1.4$ and $>1.4$, respectively (Islam et al., 2017). Hence, the characteristic of VD can be classified as very good flowability with low cohesiveness. Meanwhile, the DD powder has fair flowability and intermediate cohesiveness. The flowability of SD was fair with intermediate cohesiveness, probably due to the small particle size of the spray-dried powder. Small particle size exhibits a large surface area and provides more contact surface area for cohesive forces (Abdullah and Geldart, 1999). These particles also have high Van der Waals forces, which increases the cohesiveness of the powder (Abdullah and Geldart, 1999). The findings of this study were consistent with a study by Begum et al. (2017), who reported that spray-dried and freeze-dried jackfruit powders with smaller particle size were more cohesive and exhibited poor flow properties, thus this powder is not favourable and causes handling problems.

\section{2,2-diphenyl-1-picrylhydrazyl (DPPH) radical scavenging activity}

Figure 4 shows the $\mathrm{IC}_{50}$ of DPPH radical scavenging activity of fresh and dried 'kedondong' powder, 


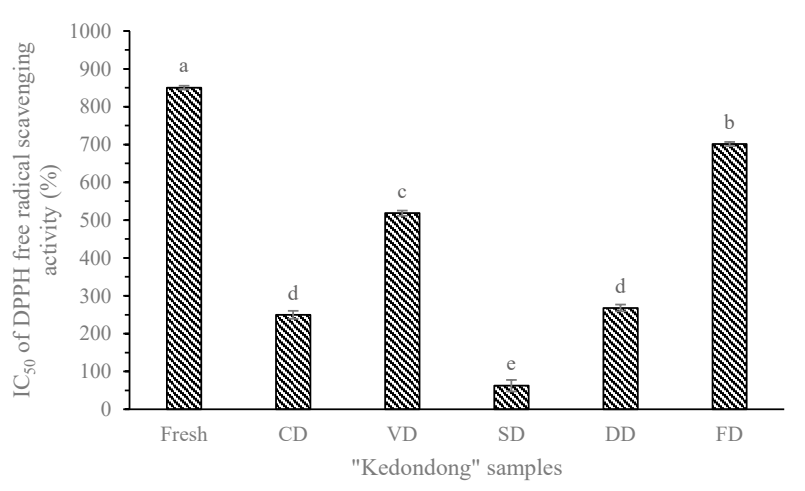

Fig. 4. $\mathrm{IC}_{50}$ of $\mathrm{DPPH}$ free radical scavenging activity of fresh 'kedondong' and dried powder produced by convection oven drying - $\mathrm{CD}$, vacuum drying - VD, spray drying $\mathrm{SD}$, drum drying - DD and freeze drying - FD

which measures the reducing ability of antioxidants toward the DPPH free radical. The significantly highest $(p \leq 0.05) \mathrm{IC}_{50}$ of DPPH scavenging activity was recorded in the fresh sample $(850.38 \pm 14.89 \mu \mathrm{g} / \mathrm{mL})$, while the SD powder exhibited the lowest activity $(62.37 \pm 5.22 \mu \mathrm{g} / \mathrm{mL})$. It is noticeable that the FD powder retained the most antioxidant properties and exhibited the highest free radical scavenging activity among the drying methods. These results were consistent with the findings of Sogi et al. (2015). In their study, freeze drying best preserved the antioxidant properties of mango cubes. The highest free radical scavenging activity being observed in freeze dried powder can be explained by the lack of heat-related damage during drying, as described by Sogi et al. (2015). Meanwhile, the high heat used in spray drying may cause the lowest DPPH activity in the SD powder as a result of thermal degradation (Caliskan and Dirim, 2013). The exposure to high temperatures adversely affected the structure of phenolic compounds and caused it to break down (Caliskan and Dirim, 2013).

\section{CONCLUSION}

In this study, 'kedondong' fruit was successfully dried into powder using different drying methods. The spray dried process yielded the highest dried powder, while drum-dried and freeze-dried powder were the lowest. Overall, the powder produced by all the drying methods had a low moisture content (3.03 to 5.66\%) and $A_{w}(0.19-0.37)$, indicating that the powders were microbiologically and biochemically stable and exhibited good shelf-stability. Visually, whitish and fine powder was observed in spray-dried and freeze-dried powders, while convection oven-dried and vacuum-dried powder appeared yellowish and coarse. The $\mathrm{pH}$ values of all the powders were slightly higher than the 'kedondong' fruit, suggesting that some acids were lost due to evaporation during drying. Interestingly, convection oven-dried powder had the lowest wettability time, indicating a higher ability to overcome surface tension to become wet. Meanwhile, spray-dried powder exhibited the shortest dissolution time. The powders under study were classified as non-caking powders, except for drum-dried powder, which was considered to be a slightly caking powder. The bulk and tapped densities of spray-dried powder were the lowest with fair flowability and intermediate cohesiveness. Lastly, the DPPH free radical scavenging activity of freeze-dried powder retained and exhibited the highest value $\left(\mathrm{IC}_{50}=850.38 \pm 14.89 \mu \mathrm{g} / \mathrm{mL}\right)$ among the drying methods. This was probably due to the low temperature used and the absence of oxygen during freeze drying, which caused it to have a minimal oxidative reaction and ultimately preserved the antioxidant components. In summary, from an industrial and economic point of view, the spray drying method was preferable as it has a high process yield and can maximise the production capacity. Moreover, spray-dried powder exhibited the better quality in terms of colour, moisture content, water activity, dissolution and degree of caking, and those characteristics demonstrate its great potential in the food industry. On the other hand, freeze drying best preserved the antioxidant properties of the powder, which could potentially be used as a functional food ingredient as a result.

\section{REFERENCES}

Abdullah, E. C., Geldart, D. (1999). The use of bulk density measurements as flowability indicators. Powder Technol., 102(2), 151-165. https://doi.org/10.1016/S00325910(98)00208-3

Ali, M. A., Yusof, Y. A., Chin, N. L., Ibrahim, M. N. (2017). Processing of Moringa leaves as natural source of nutrients by optimization of drying and grinding 
Chang, L. S., Lau, K. Q., Tan, C. P., Yusof, Y. A., Nyam, K. L., Pui, L. P. (2021). Production of 'kedondong' (Spondias cytherea Sonnerat) powder as affected by different drying methods. Acta Sci. Pol. Technol. Aliment., 20(4), 417-427. http://dx.doi.org/10.17306/ J.AFS.2021.0903

mechanism. J. Food Proc. Eng., 40(6), e12583. https:// doi.org/10.1111/jfpe. 12583

AOAC (1995). Official methods of analysis of the Association of Official Analytical Chemists (16th ed.). Gathersburg, USA: Association of Official Analytical Chemists.

Badrie, N., Schauss, A. G. (2010). Soursop (Annona muricata L.): Composition, nutritional value, medicinal uses, and toxicology. In R. R. Watson, V. R. Preedy (Eds.), Bioactive foods in promoting health (pp. 621-643). London, UK: Academic Press. https://doi.org/10.1016/ B978-0-12-374628-3.00039-6

Barbosa, J., Borges, S., Amorim, M., Pereira, M. J., Oliveira, A., Pintado, M. E., Teixeira, P. (2015). Comparison of spray drying, freeze drying and convective hot air drying for the production of a probiotic orange powder. J. Funct. Foods, 17, 340-351. https://doi.org/10.1016/j. jff.2015.06.001

Begum, R., Yusof, Y. A., Aziz, M. G., Uddin, M. B. (2017). Structural and functional properties of pectin extracted from jackfruit (Artocarpus heterophyllus) waste: Effects of drying. Int. J. Food Prop., 20(1), S190-S201. https:// doi.org/10.1080/10942912.2017.1295054

Caliskan, G., Dirim, S. N. (2013). The effects of the different drying conditions and the amounts of maltodextrin addition during spray drying of sumac extract. Food Bioprod. Proc., 91(4), 539-548.

Caparino, O. A., Tang, J., Nindo, C. I., Sablani, S. S., Powers, J. R., Fellman, J. K. (2012). Effect of drying methods on the physical properties and microstructures of mango (Philippine 'Carabao' var.) powder. J. Food Eng., 111(1), 135-148. https://doi.org/10.1016/j.jfoodeng.2012.01.010

Chang, L. S., Karim, R., Abdulkarim, S. M., Yusof, Y. A., Ghazali, H. M. (2018a). Storage stability, color kinetics and morphology of spray-dried soursop (Annona muricata L.) powder: effect of anticaking agents. Int. J. Food Prop., 21(1), 1937-1954. https://doi.org/10.1080/10942 912.2018.1510836

Chang, L. S., Karim, R., Sabo Mohammed, A., Mohd Ghazali, H. (2018b). Production and characterization of enzyme-treated spray-dried soursop (Annona muricata L.) powder. J. Food Proc. Eng., 41(e:12688). https://doi. org/10.1111/jfpe. 12688

Chang, L. S., Eau Yong, S. M., Pui, L. P. (2020a). Production of spray-dried "Terung asam" (Solanum lasiocarpum Dunal) powder. Walailak J. Sci. Technol., 18(1). https://doi.org/10.48048/wjst.2021.6922

Chang, L. S., Tan, Y. L., Pui, L. P. (2020b). Production of spray-dried enzyme-liquefied papaya (Carica papaya
L.) powder. Brazilian J. Food Technol., 23, e2019181. https://doi.org/10.1590/1981-6723.18119

Chew, S. C., Tan, C. H., Pui, L. P., Chong, P. N., Gunasekaran, B., Lin, N. K. (2019). Encapsulation technologies: A tool for functional foods development. Int. J. Innov. Technol. Expl. Eng., 8(5s), 154-160.

Franquin, S., Marcelin, A., Aurore, G., Reynes, M., Brillouet, J. M. (2005). Physicochemical characterisation of the mature green Golden apple (Spondias cytherea Sonnerat). fruits. Fruits, 60(3), 203-210.

GEA (2019). GEA Niro Method no. A14a - Hygroscopicity. Retrieved March 10, 2019, from http:/www.niro.com/ niro/cmsdoc.nsf/WebDoc/ndkw6u9cjh

Goula, A. M., Adamopoulos, K. G. (2010). A new technique for spray drying orange juice concentrate. Inn. Food Sci. Emerg. Technol., 11(2), 342-351. https://doi. org/10.1016/j.ifset.2009.12.001

Goula, A. M., Adamopoulos, K. G., Kazakis, N. A. (2004). Influence of spray drying conditions on tomato powder properties. Drying Technol., 22(5), 1129-1151. https:// doi.org/10.1081/DRT-120038584

Islam, M. Z., Kitamura, Y., Kokawa, M., Monalisa, K., Tsai, F. H., Miyamura, S. (2017). Effects of micro wet milling and vacuum spray drying on the physicochemical and antioxidant properties of orange (Citrus unshiu) juice with pulp powder. Food Bioprod. Proc., 101(2012), 132-144. https://doi.org/10.1016/j.fbp.2016.11.002

Katerson, A., Badrie, N. (2002). Sensory and physicochemical quality of 'reduced sodium' hot sauces from 'dwarf' golden apples (Spondias cytherea): Effects of brining and debrining. J. Food Sci., 67(9), 3476-3483. https:// doi.org/10.1111/j.1365-2621.2002.tb09608.x

Koç, G. Ç., Dirim, S. N. (2018). Spray dried spinach juice: Powder properties. J. Food Measur. Charact., 12(3), 1654-1668. https://doi.org/10.1007/s11694-018-9781-9

Lai, J. T., Lai, K. W., Zhu, L. Y., Nyam, K. L., Pui, L. P. (2020). Microencapsulation of Lactobacillus plantarum $299 \mathrm{v}$ and its storage in kuini juice. Malaysian J. Microbiol., 16(4), 235-244.

Michalska, A., Wojdyło, A., Lech, K., Łysiak, G. P., Figiel, A. (2016). Physicochemical properties of whole fruit plum powders obtained using different drying technologies. Food Chem., 207, 223-232. https://doi. org/10.1016/j.foodchem.2016.03.075

Mujumdar, A. S. (2015). Handbook of industrial drying. Drying technology. Boca Raton: CRC Press.

Ng, S. L., Lai, K. W., Nyam, K. L., Pui, L. P. (2019). Microencapsulation of Lactobacillus plantarum 299v incorporated with oligofructose in chitosan coated-alginate beads and its storage stability in ambarella juice. 
Malaysian J. Microbiol., 15(5), 408-418. https://doi. org/10.21161/mjm.190337

Park, H. J., Lee, Y., Eun, J. B. (2016). Physicochemical characteristics of kimchi powder manufactured by hot air drying and freeze drying. Biocatal. Agric. Biotechnol., 5, 193-198. https://doi.org/10.1016/j.bcab.2016.02.002

Pui, L. P., Karim, R., Yusof, Y. A., Wong, C. W., Ghazali, H. M. (2018). Physicochemical and sensory properties of selected 'cempedak' (Artocarpus integer L.) fruit varieties. Int. Food Res. J., 25(2), 861-869.

Pui, L. P., Karim, R., Yusof, Y. A., Wong, C. W., Ghazali, H. M. (2020). Optimization of spray-drying parameters for the production of 'Cempedak' (Artocarpus integer) fruit powder. J. Food Measur. Charact., 14, 3238-3249. https://doi.org/10.1007/s11694-020-00565-3

Santhalakshmy, S., Don Bosco, S. J., Francis, S., Sabeena, M. (2015). Effect of inlet temperature on physicochemical properties of spray-dried jamun fruit juice powder.
Powder Technol., 274, 37-43. https://doi.org/10.1016/j. powtec.2015.01.016

Sogi, D. S., Siddiq, M., Dolan, K. D. (2015). Total phenolics, carotenoids and antioxidant properties of Tommy Atkin mango cubes as affected by drying techniques. LWT - Food Sci. Technol., 62(1), 564-568. https://doi. org/10.1016/j.lwt.2014.04.015

Tan, S. P., Kha, T. C., Parks, S. E., Stathopoulos, C. E., Roach, P. D. (2015). Effects of the spray-drying temperatures on the physiochemical properties of an encapsulated bitter melon aqueous extract powder. Powder Technol., 281, 65-75. https://doi.org/10.1016/j.powtec.2015.04.074

Wong, C. W., Pui, L. P., Ng, J. M. L. (2015). Production of spray-dried Sarawak pineapple (Ananas comosus) powder from enzyme liquefied puree. Int. Food Res. J., 22(4), 1631-1636. 
